\title{
Expression of neurogenin3 reveals an islet cell precursor population in the
}

\section{pancreas}

\author{
Valérie M. Schwitzgebel ${ }^{1,2, *}$, David W. Scheel${ }^{1}$, Jennifer R. Conners ${ }^{1}$, Julie Kalamaras ${ }^{1}$, Jacqueline E. Lee ${ }^{4}$, \\ David J. Anderson ${ }^{5}$, Lori Sussel ${ }^{6}$, Jeffrey D. Johnson ${ }^{1, \ddagger}$ and Michael S. German ${ }^{1,3, \S}$ \\ ${ }^{1}$ Hormone Research Institute, ${ }^{2}$ Department of Pediatrics, and ${ }^{3}$ Department of Medicine, University of California San Francisco, \\ San Francisco, CA 94143, USA \\ ${ }^{4}$ Department of Molecular, Cellular and Developmental Biology, University of Colorado at Boulder, Colorado, USA \\ ${ }^{5}$ Howard Hughes Medical Institute, Division of Biology, California Institute of Technology, USA \\ ${ }^{6}$ Barbara Davis Center for Childhood Diabetes, University of Colorado, Denver, CO, USA \\ *Present address: Pediatric Endocrinology, Children's Hospital, University of Geneva, CH-1211 Geneva, Switzerland \\ fPresent address: Metabolex Corporation, Hayward, CA \\ §Author for correspondence (e-mail: mgerman@biochem.ucsf.edu)
}

Accepted 31 May; published on WWW 20 July 2000

\section{SUMMARY}

Differentiation of early gut endoderm cells into the endocrine cells forming the pancreatic islets of Langerhans depends on a cascade of gene activation events controlled by transcription factors including the basic helix-loop-helix (bHLH) proteins. To delineate this cascade, we began by establishing the position of neurogenin3, a bHLH factor found in the pancreas during fetal development. We detect neurogenin3 immunoreactivity transiently in scattered ductal cells in the fetal mouse pancreas, peaking at embryonic day 15.5. Although not detected in cells expressing islet hormones or the islet transcription factors Isl1, Brn4, Pax6 or PDX1, neurogenin3 is detected along with early islet differentiation factors $\mathrm{Nkx6.1}$ and $\mathrm{Nkx2.2}$, establishing that it is expressed in immature cells in the islet lineage. Analysis of transcription factor-deficient mice demonstrates that neurogenin 3 expression is not dependent on neuroD1/BETA2, Mash1, Nkx2.2, Nkx6.1, or Pax6. Furthermore, early expression of neurogenin3 under control of the $P d x 1$ promoter is alone sufficient to drive early and ectopic differentiation of islet cells, a capability shared by the pancreatic bHLH factor, neuroD1/BETA2, but not by the muscle bHLH factor, MyoD. However, the islet cells produced in these transgenic experiments are overwhelmingly $\alpha$ cells, suggesting that factors other than the bHLH factors are required to deviate from a default $\alpha$ cell fate. These data support a model in which neurogenin3 acts upstream of other islet differentiation factors, initiating the differentiation of endocrine cells, but switching off prior to final differentiation. The ability to uniquely identify islet cell precursors by neurogenin3 expression allows us to determine the position of other islet transcription factors in the differentiation cascade and to propose a map for the islet cell differentiation pathway.

Key words: Islet of Langerhans, Pancreas, Basic helix-loop-helix protein, neurogenin3, Mouse

\section{INTRODUCTION}

The pancreas forms from dorsal and ventral buds that appear at the foregut-midgut junction starting at embryonic day (E)9.5 in the mouse. Over the subsequent 10 days of fetal development, these two apparently uniform clusters of epithelial cells differentiate into the cell types that compose the adult pancreas: the endocrine cells of the islets of Langerhans, the duct cells, and the exocrine cells (for reviews see Sander et al. (1997); Slack (1995)).

The first detectable differentiated cells, starting at E9.5, are glucagon-expressing $\alpha$ cells followed sequentially by other islet cells: insulin-producing $\beta$ cells, somatostatin-producing $\delta$ cells and pancreatic polypeptide-producing PP cells (Gittes and Rutter, 1992; Herrera et al., 1991; Pictet et al., 1972; Rall et al., 1973; Teitelman et al., 1993; Upchurch et al., 1994). Based on this order of appearance, a variety of transgenic experiments, and evidence that cells expressing more than one endocrine hormone are present early in pancreatic development, several models have been proposed to explain the developmental lineage of endocrine cells (Alpert et al., 1988; Herrera et al., 1994, 1991; Teitelman et al., 1993; Upchurch et al., 1994). These models have in common the supposition that the endocrine cells formed early in pancreatic development function as progenitors of the mature islet cells found later. This assumption has never been proved by direct lineage tracing.

Alternatively, a population of undifferentiated precursor cells may persist, allowing for new islet cell formation throughout development. After E13, when ducts can first be distinguished, new endocrine cells appear adjacent to, or even embedded in the ducts (Githens, 1988; Herrera et al., 1991; 
Pictet et al., 1972; Teitelman and Lee, 1987), suggesting that either the duct cells themselves or some population of cells harbored among the duct cells may function as precursors for islet cells throughout development.

The morphologic changes that occur as endocrine cells differentiate from precursors depend on sequential changes in gene expression. Recent studies have focussed on the underlying molecular events that control these changes in gene expression. Gene disruption experiments in mice have demonstrated the importance of several transcription factors of the homeodomain family in islet cell differentiation. These include Pax6 (Sander et al., 1997; St-Onge et al., 1997) and Isl1 (Ahlgren et al., 1997), which are required for the normal formation of all islet cell types, Pax4, which is involved in the differentiation of $\beta$ and $\delta$ cells (Sosa-Pineda et al., 1997), and Nkx6.1, which is required specifically for $\beta$ cell formation (M. Sander and M. German, unpublished data). The absence of $\mathrm{Nkx} 2.2$ causes a reduction in $\alpha$ and PP cells, but also causes a specific block in late steps of $\beta$ cell differentiation (Sussel et al., 1998).

Cell-type-specific (class B) members of the basic helix-loophelix (bHLH) family of transcription factors play essential roles in the development and maintenance of many differentiated cell types. neuroD1/BETA2 is a class B bHLH factor expressed in the pancreas and involved in islet cell development and insulin gene transcription (Naya et al., 1995). Although the targeted disruption of the neuroD1/BETA2 gene in mice leads to a reduction in the endocrine cell mass at birth, this is largely due to an increase in apoptosis: endocrine cell formation is not blocked and insulin production continues in the remaining $\beta$ cells (Naya et al., 1997). The persistence of islet cell genesis suggests that other bHLH proteins also may contribute to islet cell differentiation during the development of the pancreas.

The developing pancreas expresses a second, related bHLH protein, neurogenin3 (Sommer et al., 1996b). Based on experiments showing that early expression of neurogenin 3 can cause early differentiation of islet cells, and evidence that neurogenin 3 is not expressed in mature islet cells, Apelqvist et al. (1999) have concluded that neurogenin 3 is expressed in islet cell progenitors and functions as a pro-endocrine gene driving islet cell differentiation. However, other bHLH factors, such as neuroD1/BETA2 were not tested in a similar fashion. Since many class B bHLH factors can drive terminal differentiation of a variety of cell types when expressed in the appropriate precursors (Arnold and Winter, 1998; Jan and Jan, 1993; Lee, 1997; Sommer et al., 1996a), and it was not established whether the cells normally expressing neurogenin 3 are in the islet cell lineage, it remains uncertain whether neurogenin 3 is the bHLH factor that normally functions as a pro-endocrine gene in the developing pancreas. Furthermore, it is not clear from these experiments whether neurogenin 3 is sufficient to drive the differentiation of all four islet cell types, since only glucagon expression was examined.

Neurogenin 3 is necessary, however, for the formation of all four islet cell types, since mice carrying a homozygous targeted disruption of the neurogenin3 gene lack any islet cells (Gradwohl et al., 2000). In the early pancreatic bud, neurogenin 3 mRNA can be detected by in situ hybridization in proliferating cells expressing the homeodomain protein Pdx1, but not in hormone-expressing cells, while neuroD1 mRNA is detected in a non-replicating cell population that includes mature hormone-expressing cells (Jensen et al., 2000). Together, these results have led to the hypothesis that neurogenin 3 lies upstream of neuroD1 in the pathway of islet cell differentiation, a conclusion that is supported by recent evidence that neurogenin 3 can activate the neuroD1 promoter (Huang et al., 2000).

In the present study, we clarify the position of neurogenin 3 in the hierarchy of islet transcription factors. We demonstrate by degenerate RT-PCR and in situ hybridization that islet cells and the developing pancreas express a broad group of class B bHLH genes, among the most abundant being neurogenin3 (ngn3), neuroD1/BETA2, Mash1 and neuroD4/Math3. Immunohistochemical analysis reveals that neurogenin 3 is indeed co-expressed with some markers of differentiating islet cells, including the $\beta$ cell differentiation factor Nkx6.1, thus establishing that neurogenin 3 marks islet cell precursors. In an experiment similar to that of Apelqvist et al. (1999), we confirm that neurogenin 3 can drive the early differentiation of islet cells, but also find that neuroD1/BETA2 shares this capacity. However, these transgenic experiments only produce glucagon-expressing $\alpha$ cells. Thus other signals in addition to the pro-endocrine bHLH factors are required to develop the full spectrum of islet cell types. Together with earlier studies, these results provide the framework for a more detailed map of the differentiation pathway for pancreatic islet cells.

\section{MATERIALS AND METHODS}

\section{RT-PCR}

Total cellular RNA was extracted from rat islets and mRNA was prepared from $\alpha \mathrm{TC}, \beta-\mathrm{TC} 3, \mathrm{mPAC}$ and 266 cells using the RNaqueous extraction kit (Ambion) and DNase I treatment to remove contaminating genomic DNA. Oligo(dT)-primed reverse transcription of RNA was carried out for 1 hour at $42^{\circ} \mathrm{C}$ using Superscript II (Gibco). First strand cDNA served as a template for PCR amplification as previously described (Sommer et al., 1996b) using Taq polymerase (Fisher) and the following degenerate primers derived from the helix 1 and the loop of the conserved bHLH encoding region of the neural class $\mathrm{B}$ bHLH genes $\left(5^{\prime}\right.$ primer: cgggatccAAT/CGA/CIC/AGIGAA/GC/AGIAAT/CC/AGIA/GT, 3' primer: cggaattcAG/AIGTT/CTCIAT/CT/CTTIG/CA/TIAT/G/AT/ CTT). PCR was carried out in a DNA Thermal Cycler (Perkin-Elmer) for eight cycles with a denaturation step at $94^{\circ} \mathrm{C}$ for 1 minute, annealing at $43^{\circ} \mathrm{C}$ for 1 minute and extension at $72^{\circ} \mathrm{C}$ for 1 minute, followed by an additional 40 cycles with the annealing temperature raised to $55^{\circ} \mathrm{C}$. The Taq polymerase was added at $94^{\circ} \mathrm{C}$ during the first cycle. The 127 bp PCR product was purified from a NuSieve agarose gel by Quiaquick (Quiagen), subjected to a second round of PCR ( 40 cycles of 1 minute at $90^{\circ} \mathrm{C}, 1$ minute at $5^{\circ} \mathrm{C}$, and 1 minute at $72^{\circ} \mathrm{C}$ ), digested with EcoRI and $B a m \mathrm{HI}$, and cloned into the pBlueScript (KS)+ vector (Stratagene). In total, 107 clones were characterized and identified by sequencing with the Sanger dideoxy method.

\section{In situ hybridization}

For RNA in situ hybridization analysis of paraffin sections $(5 \mu \mathrm{m})$, embryos and pancreases were processed, sectioned and hybridized with digoxigenin-labeled riboprobes as described by Neubuser et al. (1995) with some modifications. Digoxigenin-labeled sense and antisense riboprobes were detected with alkaline phosphatase-coupled anti-digoxigenin antibodies using BM purple (Boehringer Mannheim) as color substrate. Riboprobes used in this study were as follows: ngn1 
(Ma et al., 1996), ngn2 and ngn3 (Sommer et al., 1996b), neuroD1 (Lee et al., 1995), and Mash1 (Guillemot et al., 1993).

To obtain a neuroD4/Math3 probe (Takebayashi et al., 1997), a $\lambda$ ZAP (Stratagene) cDNA library prepared from the mouse insulinoma cell line $\beta$-TC3 was screened by hybridization with the PCR product encoding neuroD4. From positive clones, a full length neuroD4 cDNA was selected and confirmed by sequencing with the Sanger dideoxy method.

\section{Immunohistochemical and immunofluorescence assays}

Immunohistochemistry and immunofluorescence assays were performed on paraffin sections as described previously (Sander et al., 1997). Primary antibodies employed in these assays: mouse antiinsulin antibody (Sigma) diluted 1:10000; guinea pig anti-insulin 1:10000 (Linco, St. Charles, MI); mouse anti-glucagon 1:10000 (Sigma); guinea pig anti-glucagon 1:10000 (Linco); guinea pig antipeptide YY (kindly provided by G. Aponte (Upchurch et al., 1994)) 1:800; rabbit anti-Pax6-QNR antiserum 11 (kindly provided by S. Saule, Institut Pasteur, Lille, France) directed against the paired domain of quail PAX6 (Turque et al., 1994), diluted 1:4000; mouse anti-Isl1 (Developmental Hybridoma Bank) 1:200; monoclonal mouse anti-Nkx2.2 (kindly provided by T. Jessel) 1:50; rabbit anti-Nkx6.1 (Sussel et al., 1998) 1:6000; rabbit anti-Brn4 (kindly provided by M. G. Rosenfeld (Schonemann et al., 1995) 1:100; monoclonal mouse anti-skeletal muscle myosin heavy chain clone MF20 (Developmental Hybridoma Bank) 1:100; monoclonal mouse anti-smooth muscle actin clone 1A4, cy3-conjugated (Sigma) 1:200; mouse anti-PCNA and Ki-67 (Pharmigen) 1:4000. Secondary antibodies were used as described previously (Sander et al., 1997).

Neurogenin3 antigen was produced by inserting the coding sequence for the amino-terminal 95 amino acids from mouse neurogenin 3 downstream of the glutathione S-transferase coding sequence in the pGEX-2T vector (Pharmacia). The resulting fusion protein was purified from $E$. coli and injected into rabbits and guinea pigs. 1:5000 (rabbit) or 1:4000 (guinea pig) dilutions were used for staining, and preimmune sera from both animals gave no staining at the same concentrations. Pdx 1 antigen was produced by inserting the coding sequence for the carboxy-terminal 80 amino acids from mouse IPF1 downstream of the glutathione S-transferase coding sequence in the pGEX-2T vector (Pharmacia). The resulting fusion protein was purified from $E$. coli and injected into rabbits and guinea pigs. 1:4000 dilutions of the guinea pig antiserum were used for staining, and preimmune sera gave no staining at the same concentrations.

For immunofluorescence assays, Cy3- (Jackson ImmunoResearch Laboratories), Texas Red- and FITC-conjugated (Cappel) goat antirabbit, anti-guinea pig and anti-mouse were applied at a 1:200 dilution. Fluorescence was visualized with a Zeiss axioscope and a Leica confocal microscope.

\section{Transgenic mice}

The $P d x 1$ promoter vector pBAT.PD17 was constructed by inserting the mouse $P d x l$ promoter (a $4.4 \mathrm{~kb} X b a \mathrm{I}-S m a \mathrm{I}$ fragment from the mouse $P d x l$ gene containing the transcription start site and promoter (Apelqvist et al., 1997; Wu et al., 1997)) and the human $\beta$-globin gene first intron upstream of the pBAT polylinker (German et al., 1992) and the SV40 late gene polyadenylation signal. A 663 bp DNA fragment encoding full length mouse $n g n 3$ cDNA was obtained by PCR from the mouse genomic neurogenin 3 clone (Sommer et al., 1996b) and inserted into the pBAT.PD17 polylinker. The neuroD1/BETA2 vector was constructed by cloning into pBAT.PD17 a $1.7 \mathrm{~kb}$ DNA fragment encoding the full length mouse cDNA (Lee et al., 1995) extending from the start codon through the $3^{\prime}$ UTR. The $M y o D$ vector was constructed by cloning into pBAT.PD17 a $1 \mathrm{~kb}$ DNA fragment encoding the full length mouse cDNA (Davis et al., 1987) extending from the start codon through the first 63 bp of the 3' UTR.

The vectors were linearized and purified, and transgenic mice were generated by pronuclear injection $(1.5 \mathrm{ng} / \mu \mathrm{l})$ into $\mathrm{F}_{1}$ hybrid oocytes from C3Fe/B6 parents as described by Hogan et al. (1994). Genotypes were determined by PCR analysis of genomic DNA from tail biopsies. The primers used were: 5' TGGAGAACTGTCAAAGCGATCTG $\left(P d x 1\right.$ primer for $\left.5^{\prime}\right)$ and $5^{\prime}$ CACATGCCCAGTTTCTATTGGTC (human $\beta$-globin intron for $3^{\prime}$ ).

Embryos were harvested at E12.5 or E18.5. A total of 6 Pdxl-ngn3 animals were examined at E12.5, and 10 at E18.5. A total of 5 PdxlneuroDl animals were examined at E12.5, and 10 at E18.5. As is common in independent transgenic founders and has been seen previously in transgenic animals produced with the $P d x 1$ promoter (Apelqvist et al., 1997, 1999), these animals display a spectrum of phenotypes. At E18.5, pancreatic size varied in both groups of transgenics, from normal to the extreme micro-pancreas shown in Fig. 8. The extreme micro-pancreas was observed in two animals in each group. Less variation was observed at E12.5, when the majority of pancreases from both groups contained more glucagon-expressing cells than their littermates. Those phenotypes observed in multiple independent founders are reported. The liver in the Pdxl-ngn3 transgenic animal in Fig. 8A appears reduced in size; this abnormality was not observed in other transgenics. The transgenic animals were not grossly abnormal in size. Only a single control $P d x l-M y o D$ transgenic was sectioned and stained at E18.5; it is shown in Fig. 9.

\section{RESULTS}

\section{Expression of bHLH genes in pancreatic cell lines and islets}

Expression of mRNA encoding class B bHLH proteins was detected using a non-quantitative method of RT-PCR with degenerate oligonucleotide primers derived from the conserved bHLH-encoding region of NeuroD1/BETA2-related genes (Ma et al., 1996). cDNA was prepared from purified adult rat islets and from four mouse cell lines: the $\beta$ cell line $\beta$-TC3 (Efrat et al., 1988), the $\alpha$ cell line $\alpha$-TC1.6 (Hamaguchi and Leiter, 1990), the pancreatic ductal cell line mPAC (Yoshida and Hanahan, 1994), and the pancreatic exocrine cell line 266 (Ornitz et al., 1985). The PCR products encode 9 distinct sequences including NeuroD1/BETA2 (Lee, 1997; Naya et al., 1995), Mash1 (Guillemot et al., 1993), NeuroD2 (McCormick et al., 1996), neuroD4/Math3 (Takebayashi et al., 1997), neurogenins (ngn)1, 2 and 3 (Gradwohl et al., 1996; Ma et al., 1996; Sommer et al., 1996b), Mist1 (Lemercier et al., 1997), and meso1/scleraxis (Blanar et al., 1995; Cserjesi et al., 1995)

Table 1. Degenerate PCR of islet and pancreatic cell line cDNA*

\begin{tabular}{lccccc}
\hline & Rat islets & $\beta \mathrm{TC} 3$ & $\alpha \mathrm{TC} 1.6$ & $\mathrm{mPAC}$ & 266 \\
\hline neuroD1/BETA2 & 3 & 6 & 6 & & 1 \\
neuroD2 & 2 & 2 & & & \\
neuroD4/Math3 & 5 & 4 & 3 & 2 & 7 \\
neurogenin1 & 4 & 6 & 2 & & 1 \\
neurogenin2/Math4A & 2 & & & 1 & \\
neurogenin3 & 4 & 4 & 7 & 4 & \\
Mash1 & & 2 & 1 & & 3 \\
mist & & 2 & & \\
meso1/scleraxis & & 2 & & 3 & 11 \\
non-bHLH & & & &
\end{tabular}

*RT-PCR was performed using the degenerate oligonucleotides described in the Materials and Methods section with RNA purified from the cell types indicated. The products were subcloned and sequenced. Each number indicates how many copies of that cDNA were sequenced from the cells shown. All of the sequences that were obtained are included. 

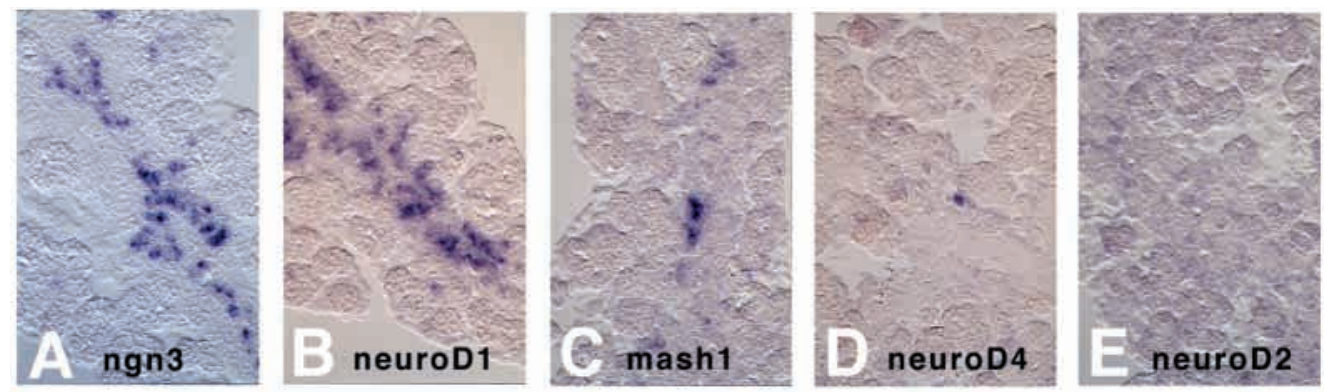

Fig. 1. Expression of bHLH genes at E15.5. In situ hybridization studies in E15.5 fetal mouse pancreas are shown for (A) ngn3, (B) NeuroD1/BETA2, (C) Mash1, (D) NeuroD4 and (E) NeuroD2. 200× magnification. Only pancreatic tissue is shown.

(Table 1). Ngn3 and NeuroD4 were found in all the pancreatic endocrine cell lines and in rat islets; NeuroD4 was also found in the exocrine cell line. Only NeuroD1/BETA2, ngn3 and mist1 were previously known to be expressed in the pancreas (Apelqvist et al., 1999; Naya et al., 1997; Naya et al., 1995; Sommer et al., 1996b). Although degenerate PCR amplification does not produce quantitative information regarding expression level, these data provide a set of bHLH cDNAs from pancreatic cells for further analysis of expression levels and patterns.

\section{Expression of bHLH factors in the pancreas in vivo}

To determine the expression pattern in vivo of the bHLH factors detected by RT-PCR, in situ hybridization studies of the developing mouse pancreas were performed. Consistent with previous studies (Apelqvist et al., 1999; Sommer et al., 1996b), this analysis detects high expression levels of ngn 3 and neuroD1 at E12.5 and E15.5 (Fig. 1 and data not shown). Low expression of Mash1 and neuroD4/Math3 can be detected at E15.5 (Fig. 1). At E12.5 neither Mash1 nor neuroD4/Math3 can be detected in the pancreas, although Mashl can be detected in scattered cells surrounding the pancreas (data not shown), probably due to expression in developing enteric neurons (Lo et al., 1991). Significant expression was not detected for neurogenins 1 and 2, or neuroD2 at any date (data not shown).

Using polyclonal antisera, ngn3 can be detected as early as E11.5 in a few epithelial cells of the pancreatic bud, at E15.5 it reaches a peak of expression, decreases at E18.5, and is undetectable in the adult pancreas (Fig. 2 and data not shown). Although we did not detect ngn3 protein in the pancreas prior to E11.5, ngn3 mRNA has been detected by in situ hybridization in scattered cells in the pancreatic bud as early as E9.5 (Apelqvist et al., 1999; Jensen et al., 2000). At E15.5 ngn3 is detected in the nuclei of scattered ductal cells and occasional periductal cells. Immunofluorescent double labeling at E15.5 shows no co-staining with several endocrine cell products, including insulin, glucagon, somatostatin, pancreatic polypeptide, islet amyloid polypeptide and peptide YY (Fig. 3 and data not shown), suggesting that if ngn3 plays a role in islet cell development, it is switched off prior to final differentiation.

Immunofluorescent double labeling was performed for ngn3 and two proteins expressed in islet cell precursors: Nkx6.1, a $\beta$ cell homeodomain transcription factor (Jensen et al., 1996; Rudnick et al., 1994); and Nkx2.2, a homeodomain factor expressed in all $\alpha, \beta$, and PP cells, and required for normal $\beta$ cell differentiation (Sussel et al., 1998). At E15.5 Nkx6.1 is coexpressed in $30-50 \%$ of cells expressing ngn3, and Nkx2.2 is expressed in 70-80\% of cells expressing ngn3 (Fig. 4). These data demonstrate that ngn3 expression marks precursor endocrine cells, and is absent from differentiated endocrine cells.

ngn3 is not co-expressed, however, with two homeodomain transcription factors normally present within the pancreatic epithelium only in fully differentiated islet cells: the LIMhomeodomain factor Isl1 (Fig. 4), which is required for the differentiation of all islet cells (Ahlgren et al., 1997); and the
Fig. 2. Expression of neurogenin 3 in the developing mouse pancreas.

Immunohistochemical staining for neurogenin 3 using rabbit anti-mouse neurogenin 3

(1:5000) and peroxidase labeled goat anti-rabbit $\operatorname{IgG}(1: 1000)$ in fetal mouse pancreas (A) at E11.5, (B) at E12.5, (C) at E15.5 and (D) at E18.5 (200x magnification). Arrows in A and $\mathrm{D}$ indicate nuclei expressing ngn3. Inset in $\mathrm{C}$ at $400 \times$ magnification shows nuclei staining for ngn3 in cells lining a duct.
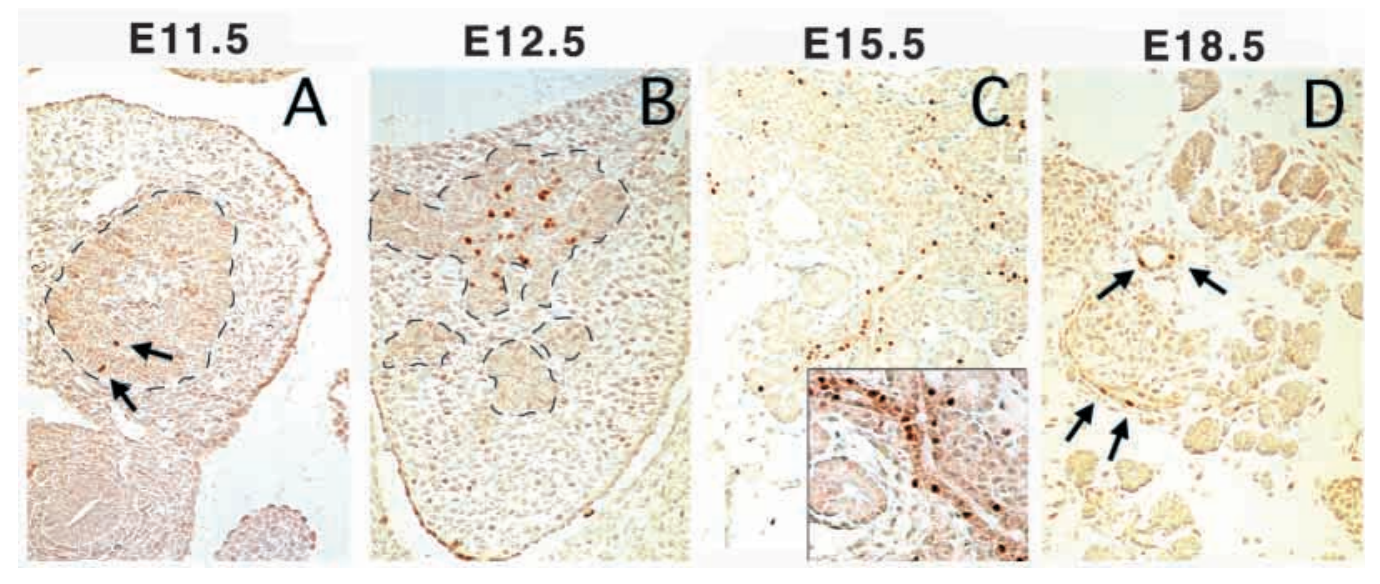

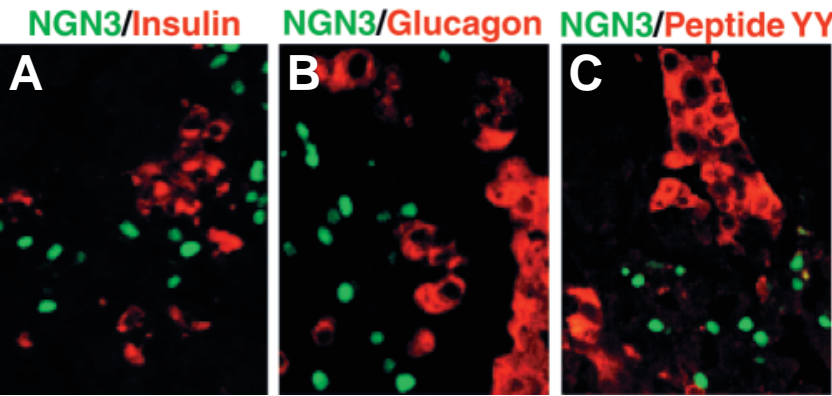

Fig. 3. Double immunofluorescence staining in fetal mouse pancreas at E15.5 with (A) with anti-insulin serum (cy3 label, red) and antingn3 serum (fluorescein label, green); (B) anti-glucagon serum (cy3 label, red) and anti-ngn3 serum (fluorescein label, green), and (C) anti-peptide YY serum (cy3 label, red) and anti-ngn3 serum (fluorescein label, green). Photomicrographs imaged confocally. $400 \times$ magnification.

paired homeodomain factor Pax6 (data not shown), which is involved in islet formation and islet hormone synthesis (Sander et al., 1997; St-Onge et al., 1997). At E15.5 ngn3 is also not co-expressed with Brn4, a Pou-homeodomain transcription factor found in $\alpha$ cells (Hussain et al., 1997), or with Pdx1, a homeodomain transcription factor largely restricted to $\beta$ and $\delta$ cells at this stage (Fig. 4). These results place these four factors late in the differentiation pathway.

\section{Pancreatic expression of ngn3 in mice lacking islet transcription factors}

To place ngn3 in the hierarchy of transcription factors involved in islet development, animals with targeted disruptions or mutations of several islet transcription factor genes were examined for ngn3 expression. Mice homozygous for a targeted disruption of the NeuroD1/BETA2 or Mash1 genes were examined at E18.5, and $N k x 6.1$ and $N k x 2.2$ null animals were examined at E15.5 and E18.5. In all of these animals, ngn3 is still expressed at levels equivalent to the levels in wildtype littermates (Fig. 5, and data not shown). ngn3 is also expressed in pancreases of embryos homozygous for the Pax6 mutant allele, Sey ${ }^{\mathrm{Neu}}$ (loss of function mutation) (Fig. 5).

The pancreases of mice lacking Mashl were also examined for differences in islet development. At E18.5, no obvious abnormalities can be detected in islet morphology or the expression patterns of the islet hormones insulin, glucagon, somatostatin and PP (Fig. 6 and data not shown).

The expression levels of ngn 3 in these mutant animals demonstrate that its expression is not dependent on any one of these transcription factors, and together with the co-staining data suggest a function upstream of Nkx6.1, Nkx2.2 and Pax6.

\section{Transgenic expression of bHLH factors}

To further investigate the function of ngn3, transgenic mice over-expressing ngn 3 early during development were created using the $P d x l$ promoter to drive expression of a mouse $n g n 3$ cDNA in pancreatic progenitor cells. Pdx1 is a homeodomain transcription factor expressed in the gut endoderm near the foregut-midgut junction prior to formation of the pancreas (E8.5). As the gut matures, scattered expression of Pdx1 persists in the duodenum and antral stomach. When the dorsal and ventral pancreatic buds form (E9.5-E10.5), Pdx1 then is expressed broadly in the epithelial cells forming the pancreatic bud, but is inactivated in the few endocrine cells (mostly $\alpha$ cells with rare $\beta$ cells) that differentiate at this stage. Starting around E13, Pdx 1 expression becomes limited to $\beta$ cells and $\delta$ cells (Guz et al., 1995; Offield et al., 1996; Ohlsson et al., 1993; Oster et al., 1998). The portion of the mouse $P d x l$ promoter used in these studies is sufficient to drive the expression of linked genes in the same pattern (Apelqvist et al., 1997; Gerrish et al., 2000; Wu et al., 1997).

Founder mice were analyzed at E12.5 and E18.5. Similar to a previous report (Apelqvist et al., 1999), at E12.5 in mice over-expressing ngn3, there is a marked increase in the number of glucagon-expressing cells in the pancreatic buds relative to wild-type litter mates, with most of the cells converted to an $\alpha$ cell fate (Fig. 7). Glucagon staining can also be detected in a few cells lining the duodenum near the pancreas (Fig. 7D) and the antral stomach in some transgenic animals indicating that expression of ngn 3 in areas of Pdx 1 expression outside the pancreas (Offield et al., 1996) can induce the development of ectopic endocrine cells.

Transgenic animals were examined for ectopic expression of the $n g n 3$ transgene, but none was detected. This result is not surprising since the $P d x l$ promoter driving the $n g n 3$ transgene
NGN3/Nkx2.2

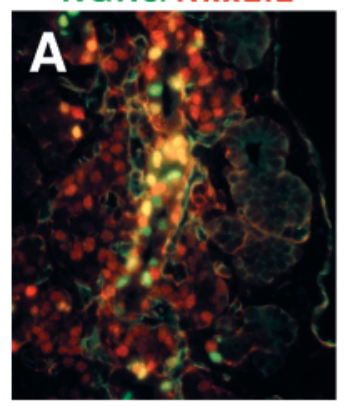

NGN3/Nkx6.1

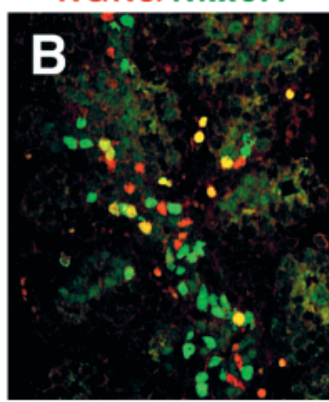

NGN3/Is!1

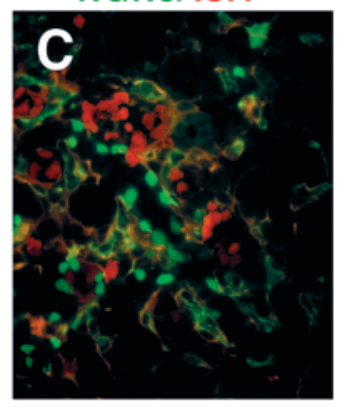

NGN3/Brn4

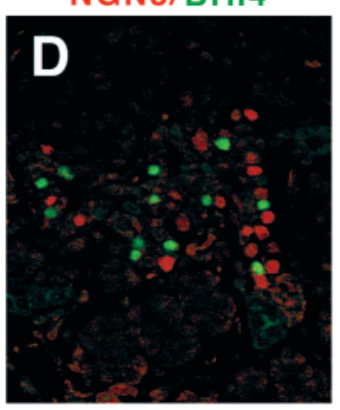

NGN3/Pdx1

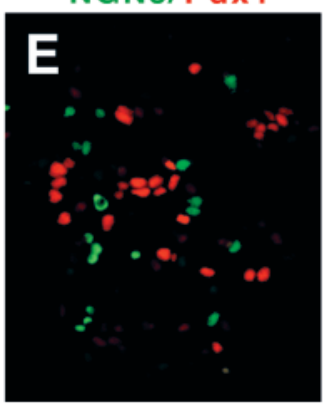

Fig. 4. Transcription factor co-expression in developing islet cells. Double immunofluorescence staining is shown at E15.5 with (A) antiNkx2.2 serum (cy3 label, orange) and anti-ngn3 serum (fluorescein label, green), (B) anti-Nkx6.1 serum (fluorescein label, green) and antingn3 serum (cy3 label, orange), (C) anti-Isl1 serum (cy3 label, orange) and anti-ngn3 serum (fluorescein label, green), (D) anti-Brn4 serum (fluorescein label, green) and anti-ngn3 serum (cy3 label, orange), and (E) anti-Pdx1 serum (cy3 label, orange) and anti-ngn3 serum (fluorescein label, green). Photomicrographs in B,C, and D were confocally imaged. Note the yellow staining in the co-staining nuclei in A and B. 400× magnification. 


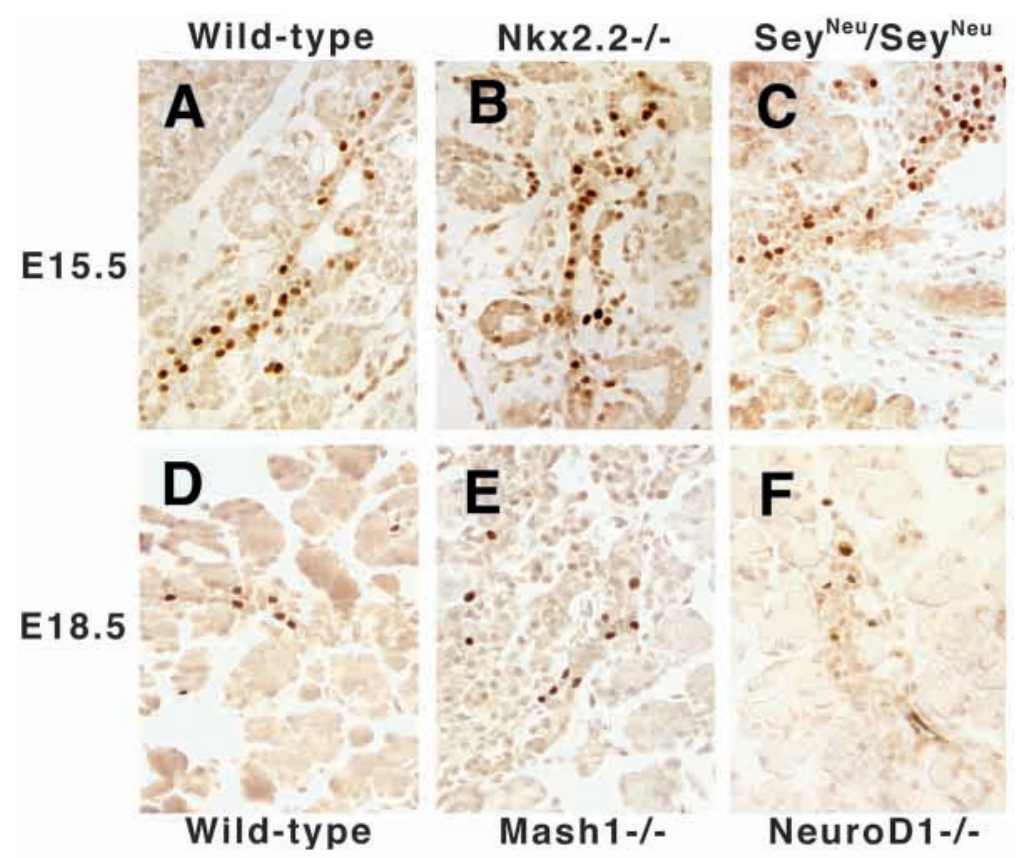

Fig. 5. Neurogenin 3 expression in mutant mice. Immunohistochemical staining for neurogenin3 is shown at E15.5 (A-C) and E18.5 (D-F) in the pancreas of mice with the following transcription factor mutations: (A) $N k x 2.2^{+/+}$, (B) $N k x 2.2^{-/-}$, (C) Sey ${ }^{\mathrm{Neu}} / \mathrm{Sey}^{\mathrm{Neu}}$ (Pax6 null mutation), (D) Mash1 $^{+/+}$, (E) Mash1 ${ }^{-1-}$, (F) neuroD1/BETA2 ${ }^{-1-}$ as positive control. 400× magnification. In each panel, neurogenin 3 can be detected in the nuclei of cells scattered along a large duct within the pancreatic parenchyma.

is not active in $\alpha$ cells, the predominant cell type in these pancreases (Gerrish et al., 2000; Wu et al., 1997). We presume that $n g n 3$ is expressed in progenitor cells at an early stage (Offield et al., 1996), but is extinguished in the differentiated cells examined at E12.5. To test the possibility that the increase

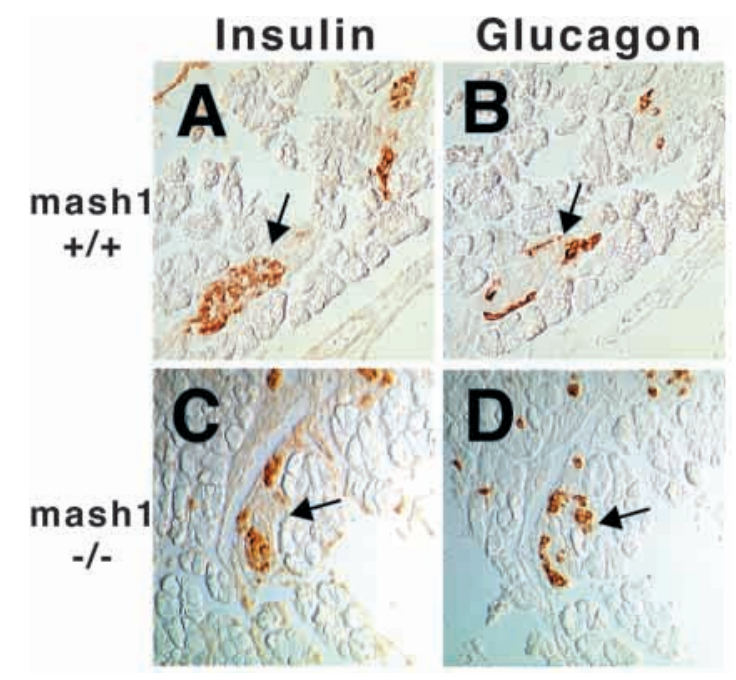

Fig. 6. Insulin and glucagon expression in mice lacking Mash1. Immunohistochemical staining is shown for insulin $(A, C)$ and glucagon $(\mathrm{B}, \mathrm{D})$ in pancreases at E18.5 from Mash1 $1^{+/+}(\mathrm{A}, \mathrm{B})$ and Mash1 $1^{-/}$(C,D) animals. (200× magnification). In each panel, the arrow indicates a forming islet, with insulin-expressing $\beta$ cells in the center surrounded by glucagon-expressing $\alpha$ cells. in $\alpha$ cells is due to increased proliferation, E12.5 transgenic pancreas was tested for the presence of markers for dividing cells, PCNA and Ki-67, by immunohistochemistry; the $\alpha$ cells did not express these proliferation markers (Fig. $7 F$ and data not shown). Given the premature increase in $\alpha$ cells in conjunction with the depletion of undifferentiated precursor cells in the E12.5 pancreas, we conclude that the increase in the $\alpha$ cell population results from premature differentiation of pancreatic epithelial cells expressing the $n g n 3$ transgene into $\alpha$ cells.

By E18.5, transgenic animals show a dramatic decrease of the size of the pancreas (Fig. 8A), consistent with the depletion of precursors due to premature differentiation into a non-dividing population of mature cells. At E18.5 the fraction of endocrine cells is grossly increased, and this increase can be accounted for by an increase in the proportion of glucagon-expressing cells (Fig. 9). In addition, the glucagon-positive cells are no longer limited to the periphery of islets as in the wild-type littermates, but now fill out entire islets. Double immunofluorescence labeling for glucagon and insulin confirms the predominance of glucagon over insulin, but does not detect any cells expressing both hormones (Fig. 9I).

Transgenic mouse embryos expressing NeuroD1/ BETA2 under control of the $P d x 1$ promoter were also examined at E12.5 and E18.5. Like the ngn3 transgenic animals, these animals demonstrate early differentiation of endocrine cells, with a marked reduction or absence of duct and exocrine structures (Figs 7C, 8B, 9E,F). Again the overwhelming majority of endocrine cells express glucagon.

Finally, to determine the specificity of the effects of ngn3 and NeuroD1/BETA2 on pancreas development, transgenic mice over-expressing $M y o D$, a class B bHLH gene normally expressed during muscle development and not normally expressed in the pancreas (Sassoon et al., 1989), were examined. In common with ngn3 and neuroD1/BETA2, transgenic expression of $M y o D$ results in a decrease in the size of the pancreas at E18.5; but there is a decrease in endocrine cells, especially insulin-expressing cells (Fig. 9G,H). In addition, $M y o D$ expression results in the formation of strands of multinucleated cells that express the muscle-specific proteins, smooth muscle actin (a marker also found in embryonic skeletal muscle; Woodcock-Mitchell et al., 1988) and skeletal muscle myosin heavy chain (Fig. 9J and data not shown).

\section{DISCUSSION}

These studies demonstrate that the developing pancreas and mature islet cells express a variety of class B bHLH genes. Not all of these genes are expressed at substantial levels as gauged by in situ hybridization, nor are they all expressed at the same time. None the less, the proteins encoded by some of these genes, especially the multiple members of the neurogenin and neuroD family (Lee, 1997; Sommer et al., 1996b), are remarkably closely related; and their overlapping expression suggests a significant degree of redundancy. 
Fig. 7. Expression of islet hormones in transgenic mice at E12.5. Immunohistochemical staining is shown for glucagon in pancreases of a nontransgenic littermate (A) and transgenic fetuses expressing ngn3 (B) or neuroD1/BETA2 (C) (200× magnification). (D) Immunohistochemical staining for glucagon in the adjacent duodenum from the animal in B demonstrates scattered glucagonexpressing cells in the gut epithelium (400X magnification). (E,F) Serial sections of the pancreas and surrounding tissue from a transgenic fetus expressing ngn3 showing immunohistochemical staining for glucagon (E) and the proliferating cell nuclear antigen PCNA (F) (150× magnification). The glucagon expressing pancreatic epithelium in $\mathrm{E}$ is outlined with a dashed line that is superimposed on the serial section in $\mathrm{F}$.
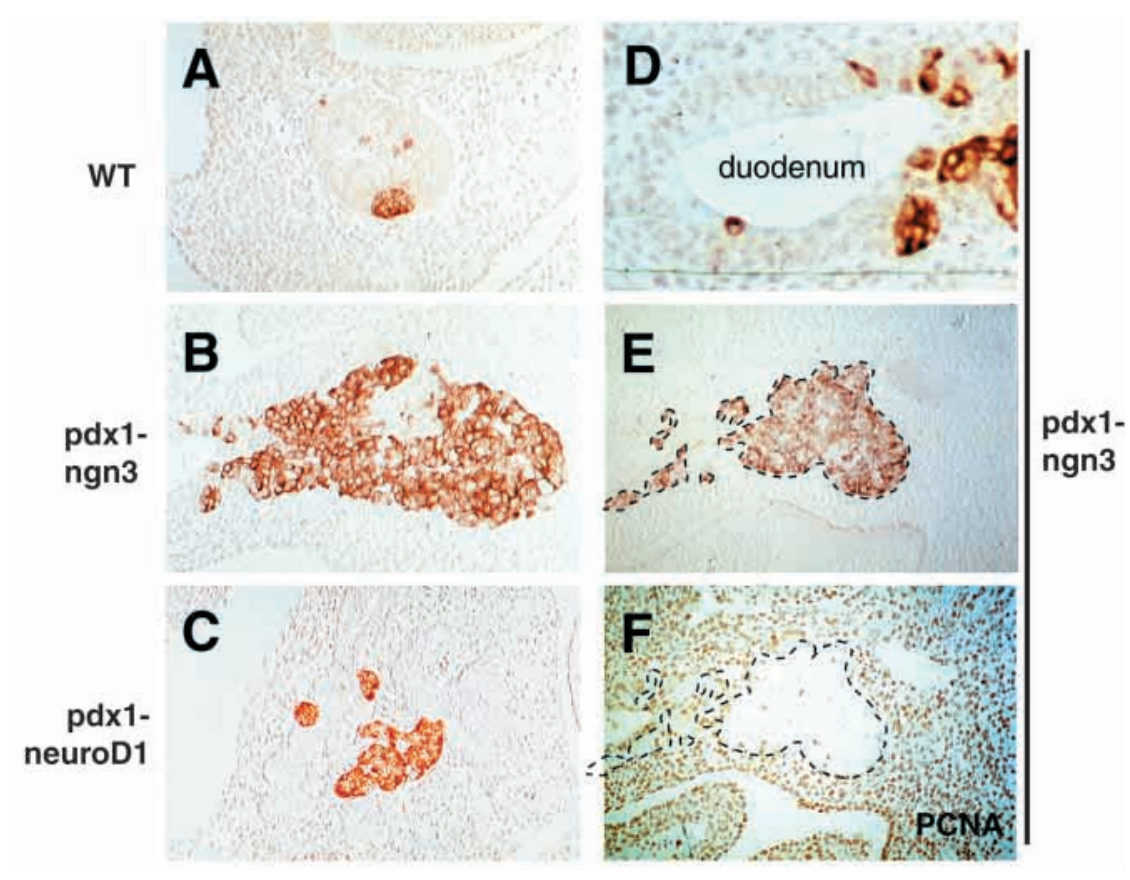

The presence of multiple bHLH factors in the pancreas is not surprising, since a similar degree of redundancy has been noted in the development and maintenance of other organ systems such as muscle or nervous system (Jan and Jan, 1993; Molkentin and Olson, 1996). This redundancy could explain the modest phenotype of mice lacking NeuroD1/BETA2 (Naya et al., 1997). However, although neurogenin 3 is present in the NeuroD1/BETA2 null animals, its expression is neither increased nor prolonged relative to the wild-type littermates, indicating that neurogenin 3 does not compensate for the absence of neuroD1/BETA2.

Differences in the pattern and timing of expression of the bHLH genes in the developing pancreas suggests that their functions are not completely redundant, and they may have overlapping but distinct roles in the gene expression events controlling differentiation. The Mash genes are the mammalian homologues of the Drosophila proneuronal achaete-scute genes (Johnson et al., 1990), and in some examples Mash1 lies upstream of members of the neurogenin and neuroD gene families in the cascade of transcription factors controlling mammalian neural development (Cau et al., 1997; Lee, 1997). In the pancreas, however, Mash1 is not required either for expression of neurogenin 3 or for endocrine differentiation. The absence of a pancreatic phenotype in animals lacking Mash1 could indicate the presence of functionally redundant factors at this step in pancreatic development, but its level of expression as indicated by in situ hybridization suggests that Mash1 may not be an important regulator of pancreatic endocrine cell differentiation.

Instead of Mash1, neurogenin3 or neuroD1 may be the furthest upstream members of the class B bHLH family and fill the role of the proneuronal genes in islet development. Members of both the neurogenin and neuroD families can drive vertebrate neurogenesis (Lee et al., 1995; Ma et al., 1996), and both neurogenin 3 and neuroD1 can individually drive endocrine cell genesis. But which of these genes fills this role in vivo? The phenotype of animals lacking neuroD1 or Mash1 and its expression pattern suggest that neurogenin 3 is the earliest pro-endocrine bHLH gene expressed. In contrast, animals lacking neurogenin3 fail to express neuroD1 (Gradwohl et al., 2000), suggesting that the role of neurogenin3 may be to activate neuroD1, which in turn directs endocrine cell differentiation, similar to the proposed role of neurogenins
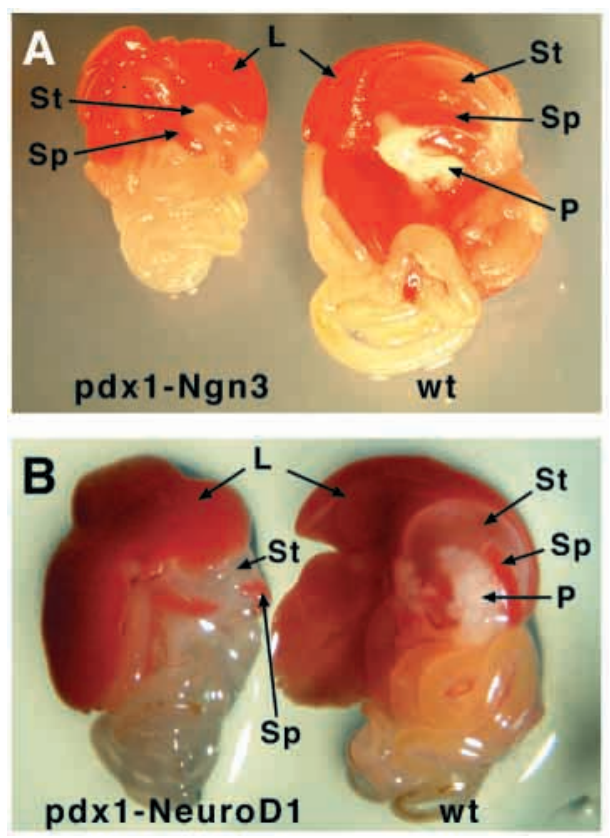

Fig. 8. Gross anatomy of the gut and associated organs of transgenic animals at E18.5 over expressing (A) ngn3 or (B) neuroD1 under the control of the $P d x l$ promoter. Non-transgenic littermates are shown at the right in each panel (wt). Arrows points to the following organs: liver (L), stomach (St), spleen (Sp), and pancreas (P). Reduced pancreatic tissue is not visible in the transgenic animals. Reductions in the stomach and small intestine are also visible in the transgenic animals. 


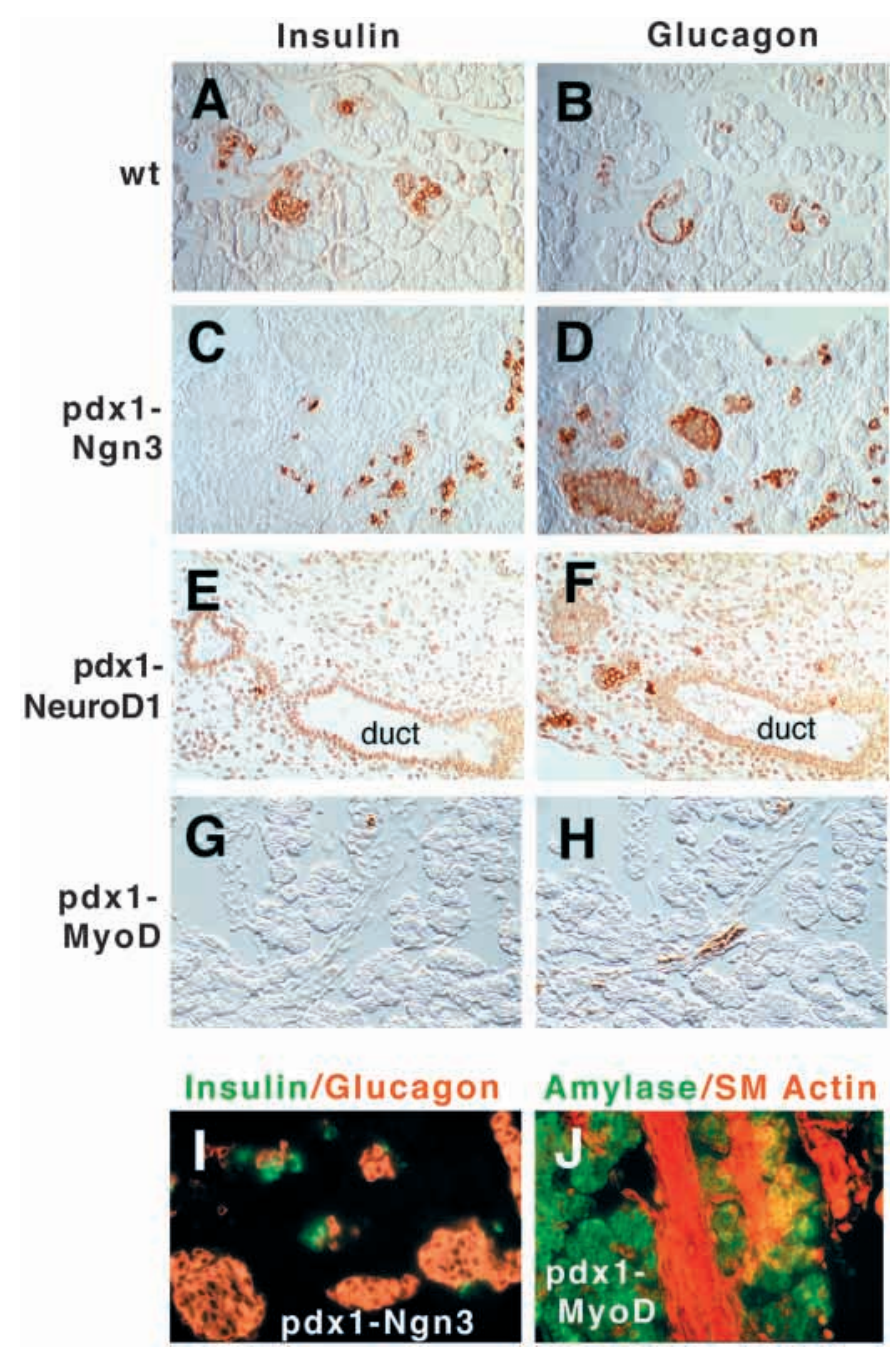

Fig. 9. Expression of islet hormones in transgenic mice at E18.5. Immunohistochemical staining is shown for insulin (A,C,E,G) and glucagon $(\mathrm{B}, \mathrm{D}, \mathrm{F}, \mathrm{H})$ in pancreases of a wild-type fetus $(\mathrm{A}, \mathrm{B})$ and transgenic fetuses expressing ngn3 (C,D), neuroD1/BETA2 (E,F) or MyoD $(\mathrm{G}, \mathrm{H})$ under the control of the $P d x l$ promoter. E and $\mathrm{F}$ show a single large duct with a small clump of remaining pancreatic tissue staining predominantly for glucagon. (I) Immunoflourescent staining for glucagon (cy3 label, orange) and insulin (fluorescein label, green) in the pancreas of a transgenic fetus expressing ngn3 at E18.5.

(J) Immunoflourescent staining for smooth muscle actin (cy3 label, orange) and amylase (fluorescein label, green) in the pancreas of a transgenic fetus expressing MyoD, at E18.5. (200× magnification). Only pancreatic tissue is shown, with the exception of $\mathrm{E}$ and $\mathrm{F}$ which include surrounding loose connective tissue.

in initiating neuroD expression during neural development (Lee, 1997; Ma et al., 1996). Although not the only possible explanation, the expression and transgenic studies are consistent with this model, as shown in Fig. 10. Recent studies of the mouse neuroD1 promoter also support the conclusion that neurogenin 3 directly activates neuroD1 expression (Huang et al., 2000).

The transgenic animal experiments demonstrate that neurogenin 3 and neuroD1/BETA2 drive endocrine differentiation; but the cell fate induced by ectopic ngn3 expression in these experiments is predominantly or

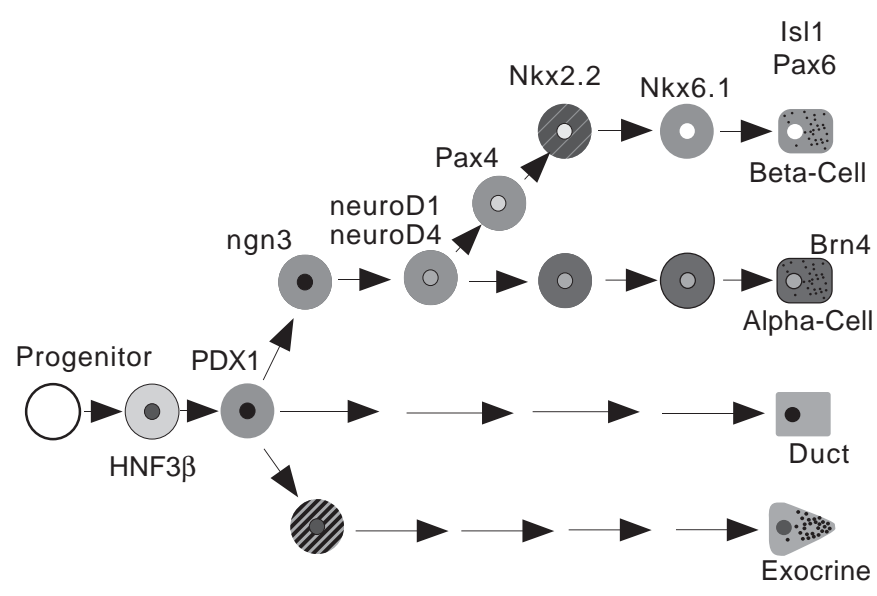

Fig. 10. Model for the role of ngn 3 in endocrine differentiation in the mouse pancreas. The proposed position for each transcription factor is based on its timing of expression, timing of predominant functional role, or both. Clearly some factors function at several steps, but a single step is shown for simplicity.

exclusively $\alpha$ cells. Although it is possible that endogenous neurogenin 3 only drives $\alpha$ cell differentiation, the coexpression of neurogenin3 with beta cell transcription factor Nkx6.1 during normal development strongly suggests the involvement of neurogenin 3 in the differentiation of other pancreatic endocrine cells. In addition, the recent targeted disruption of the neurogenin 3 gene in mice demonstrates that neurogenin 3 is required for the formation of all four endocrine cell lineages (Gradwohl et al., 2000). Alternatively, the predominance of $\alpha$ cells in the transgenic animals could result from the abnormally early and broad expression of the transgenes under control of the $P d x l$ promoter. By E12.5 in the transgenic animals, the majority of cells in the pancreas have already differentiated, and the marked reduction in the size of the pancreas at E18.5 demonstrates that little further growth occurs. Normally in non-transgenic mice very few insulinproducing cells appear in the pancreas prior to E13, presumably due to the lack of factors such as Pax4 (Smith et al., 1999) that are required for $\beta$ cell differentiation (SosaPineda et al., 1997). These results suggest a model in which $\alpha$ cells are the default result of neurogenin 3 expression, and additional signals are required to deviate neurogenin3expressing progenitor cells to alternate cellular fates such as $\beta$ cells (Fig. 10).

The ability to identify endocrine precursor cells based on neurogenin 3 expression allows us to refine prior models of the cascade of transcription factors controlling islet cell differentiation (Edlund, 1998; Guz et al., 1995; Jensen et al., 2000; St-Onge et al., 1999). Combining our data with previous genetic and functional studies, we propose a model in Fig. 10 that places many of the key islet transcription factors on a map of islet cell differentiation. Rigorous genetic proof is lacking for some points on the map, but hopefully this proposed model will provide a basis for further studies and a frame work for future refinements.

It must be noted that our data is not in agreement with previous proposals that early cells expressing glucagon, $\mathrm{PP}$ or peptide YY function as precursors of other islet cells (Alpert et al., 1988; Herrera et al., 1994, 1991; Teitelman et al., 1993; 
Upchurch et al., 1994). In the transgenic experiments the dramatically increased early pool of $\alpha$ cells does not result in the further differentiation of these cells to other islet cell types, even by E18.5. In the normal, non-transgenic animals, the absence of cells co-expressing multiple islet hormones during the peak of neurogenin3 expression and endocrine cell neogenesis (E15) suggests that islet cell type fate is determined prior to hormone expression. This conclusion is supported by the presence of the $\beta$ cell transcription factor Nkx6.1 in some neurogenin3-expressing precursors. Nkx6.1 is never seen in glucagon-expressing cells (M. Sander and M. S. G., unpublished data; Oster et al., 1998), suggesting that these cells co-expressing neurogenin 3 and Nkx6.1 are already determined to follow a $\beta$ cell fate. We propose that both $\beta$ cells and $\alpha$ cells independently derive from a non-hormone-expressing precursor that expresses neurogenin3, and islet cell type decisions are made prior to the expression of hormones.

This model does not address whether neurogenin3expressing cells represent a sustained stem cell population, or a transient state through which individual progenitor cells progress. By definition, stem cells regenerate themselves while producing new differentiated cells. In contrast, the transgenic experiments show that neurogenin 3 forces cells to differentiate and does not allow cells to remain in the undifferentiated state. This does not mean that there are no endocrine stem cells, but rather that if such cells exist, they do not express neurogenin3. The massive early differentiation of endocrine cells in the transgenic experiments demonstrates that prior to E13 most of the epithelial cells of the pancreas retain the capacity to differentiate into endocrine cells. The appearance of neurogenin3-expressing cells among the duct cells after E13 suggests that the ability to respond to neurogenin 3 and to differentiate into endocrine cells persists in the duct cells after E13, and that duct cells may effectively function as endocrine stem cells.

Do duct cells in the mature pancreas retain the capacity to differentiate into endocrine cells? Experiments in pancreatic regeneration suggest that they may (Slack, 1995). If the adult duct cells can respond to the pro-endocrine bHLH genes, then in combination with other signals these genes potentially could be used to induce new $\beta$ cell formation to replace the $\beta$ cells lost to autoimmune destruction in individuals with type 1 diabetes.

We thank the following for generously providing reagents: T. Jessel for the anti-Nkx2.2 antibody, S. Saule for the anti-Pax6 antibody, C. Wright for the mouse Pdx1 genomic clone, E. Olsen for the mouse $M y o D$ cDNA, F. Guillemot for the mouse Mash1 cDNA, and S. J. Tapscott for the mouse neuroD2 cDNA. We also thank J. Wang and Y. Zhang for excellent technical assistance and M. Hebrok and members of the German laboratory for helpful discussion. This work is supported by grants from the Juvenile Diabetes Foundation International (V. M. S. and J. E. L.), the Hopital Cantonal Universitaire Geneva, Switzerland (V. M. S.), the Nora Eccles Treadwell Foundation (M. S. G.) and the National Institutes of Health (DK48281 and DK21344, M. S. G.; NS35118, J. E. L.).

\section{REFERENCES}

Ahlgren, U., Pfaff, S. L., Jessell, T. M., Edlund, T. and Edlund, H. (1997). Independent requirement for ISL1 in formation of pancreatic mesenchyme and islet cells. Nature 385, 257-260.
Alpert, S., Hanahan, D. and Teitelman, G. (1988). Hybrid insulin genes reveal a developmental lineage for pancreatic endocrine cells and imply a relationship with neurons. Cell 53, 295-308.

Apelqvist, A., Ahlgren, U. and Edlund, H. (1997). Sonic hedgehog directs specialised mesoderm differentiation in the intestine and pancreas. Curr Biol 7, 801-804

Apelqvist, A., Li, H., Sommer, L., Beatus, P., Anderson, D. J., Honjo, T., Hrabe de Angelis, M., Lendahl, U. and Edlund, H. (1999). Notch signalling controls pancreatic cell differentiation. Nature 400, 877-881.

Arnold, H. H. and Winter, B. (1998). Muscle differentiation: more complexity to the network of myogenic regulators. Curr. Opin. Genet. Dev. 8, 539-544.

Blanar, M. A., Muslin, A. J., Crossley, P. H., Peters, K. G., Steingrimsson, E., Copeland, N. G., Jenkins, N. A., Martin, G. R. and Rutter, W. J. (1995). Meso1, a bHLH protein involved in mammalian presomitic mesoderm development. Proc. Natl. Acad. Sci. USA 92, 5870-5874.

Cau, E., Gradwohl, G., Fode, C. and Guillemot, F. (1997). Mash1 activates a cascade of bHLH regulators in olfactory neuron progenitors. Development 124, 1611-1621.

Cserjesi, P., Brown, D., Ligon, K. L., Lyons, G. E., Copeland, N. G., Gilbert, D. J., Jenkins, N. A. and Olson, E. N. (1995). Scleraxis: a basic helix-loop-helix protein that prefigures skeletal formation during mouse embryogenesis. Development 121, 1099-1110.

Davis, R. L., Weintraub, H. and Lassar, A. B. (1987). Expression of a single transfected cDNA converts fibroblasts to myoblasts. Cell 51, 987-1000.

Edlund, H. (1998). Transcribing pancreas. Diabetes 47, 1817-1823.

Efrat, S., Linde, S., Kofod, H., Spector, D., Delannoy, M., Grant, S., Hanahan, D. and Baekkeskov, S. (1988). Beta-cell lines derived from transgenic mice expressing a hybrid insulin gene-oncogene. Proc. Natl. Acad. Sci. USA 85, 9037-9041.

German, M. S., Wang, J., Chadwick, R. B. and Rutter, W. J. (1992) Synergistic activation of the insulin gene by a LIM-homeodomain protein and a basic helix-loop-helix protein: building a functional insulin minienhancer complex. Genes Dev. 6, 2165-2176.

Gerrish, K., Gannon, M., Shih, D., Henderson, E., Stoffel, M., Wright, C. V. E. and Stein, R. (2000). Pancreatic beta-cell-specific transcription of the pdx-1 gene: the role of conserved upstream control regions and their hepatic nuclear factor 3beta sites. J. Biol. Chem. 275, 3485-3492.

Githens, S. (1988). The pancreatic duct cell: proliferative capabilities, specific characteristics, metaplasia, isolation, and culture. J. Pediatr. Gastroenterol. Nutr. 7, 486-506.

Gittes, G. and Rutter, W. J. (1992). Onset of cell-specific gene expression in the developing mouse pancreas. Proc. Natl. Acad. Sci. USA 89, 1128-1132.

Gradwohl, G., Dierich, A., LeMeur, M. and Guillemot, F. (2000). Neurogenin 3 is required for the development of the four endocrine cell lineages of the pancreas. Proc. Nat. Acad. Sci.s USA 97, 1607-1611.

Gradwohl, G., Fode, C. and Guillemot, F. (1996). Restricted expression of a novel murine atonal-related bHLH protein in undifferentiated neural precursors. Dev. Biol. 180, 227-241.

Guillemot, D., Lo, L.-X., Johnson, J. E., Auerbach, A., Anderson, D. J. and Joyner, A. L. (1993). Mammalian achaete-scute homolog 1 is required for the early development of olfactory and autonomic neurons. Cell 75, 463476.

Guz, Y., Montminy, M. R., Stein, R., Leonard, J., Gamer, L. W., Wright, C. V. and Teitelman, G. (1995). Expression of murine STF-1, a putative insulin gene transcription factor, in beta cells of pancreas, duodenal epithelium and pancreatic exocrine and endocrine progenitors during ontogeny. Development 121, 11-18.

Hamaguchi, K. and Leiter, E. (1990). Comparison of cytokine effects on mouse pancreatic $\alpha$-cell and $\beta$-cell lines. Viability, secretory function and MHC antigen expression. Diabetes 39, 415-425.

Herrera, P.-L., Huarte, J., Zufferey, R., Nichols, A., Mermillod, B. Philippe, J., Muniesa, P., Sanvito, F., Orci, L. and Vassalli, J.-D. (1994). Ablation of islet endocrine cells by targeted expression of hormonepromoter-driven toxigenes. Proc. Natl. Acad. Sci. USA 91, 12999-13003.

Herrera, P. L., Huarte, J., Sanvito, F., Meda, P., Orci, L. and Vassalli, J. D. (1991). Embryogenesis of the murine endocrine pancreas; early expression of pancreatic polypeptide gene. Development 113, 1257-1265.

Hogan, B., Beddington, R., Constantitni, F. and Lacey, E. (1994). Manipulating the mouse embryo: A Laboratory Manual. New York: Cold Spring Harbour Laboratory Press.

Huang, H.-P., Liu, M., El-Hodiri, H., Chu, K., Jamrich, M. and Tsai, M.J. (2000). Regulation of the pancreatic islet-specific gene BETA2 (neuroD) by neurogenin3. Mol. Cell. Biol. 20, 3292-3307. 
Hussain, M. A., Lee, J., Miller, C. P. and Habener, J. F. (1997). POU domain transcription factor brain 4 confers pancreatic alpha-cell-specific expression of the proglucagon gene through interaction with a novel proximal promoter G1 element. Mol. Cell Biol. 17, 7186-7194.

Jan, Y. N. and Jan, L. Y. (1993). HLH proteins, fly neurogenesis, and vertebrate myogenesis. Cell 75, 827-830.

Jensen, J., Heller, R. S., Funder-Nielsen, T., Pedersen, E. E., Lindsell, C., Weinmaster, G., Madsen, O. D. and Serup, P. (2000). Independent development of pancreatic alpha and beta cells from neurogenin3expressing precursors: a role for the notch pathway in repression of premature differentiation. Diabetes 49, 163-176.

Jensen, J., Serup, P., Karlsen, C., Nielsen, T. F. and Madsen, O. D. (1996). mRNA profiling of rat islet tumors reveals nkx 6.1 as a beta-cell-specific homeodomain transcription factor. J. Biol. Chem. 271, 18749-18758.

Johnson, J. E., Birren, S. J. and Anderson, D. J. (1990). Two rat homologues of Drosophila achaete-scute specifically expressed in neuronal precursors. Nature 346, 858-861.

Lee, J. E. (1997). Basic helix-loop-helix genes in neural development. Curr. Opin. Neurobiol. 7, 13-20.

Lee, J. E., Hollenberg, S. M., Snider, L., Turner, D. L., Lipnick, N. and Weintraub, H. (1995). Conversion of Xenopus ectoderm into neurons by NeuroD, a basic helix-loop-helix protein. Science 268, 836-844.

Lemercier, C., To, R. Q., Swanson, B. J., Lyons, G. E. and Konieczny, S. F. (1997). Mist1: a novel basic helix-loop-helix transcription factor exhibits a developmentally regulated expression pattern. Dev. Biol. 182, 101-113.

Lo, L. C., Johnson, J. E., Wuenschell, C. W., Saito, T. and Anderson, D. J. (1991). Mammalian achaete-scute homolog 1 is transiently expressed by spatially restricted subsets of early neuroepithelial and neural crest cells. Genes Dev. 5, 1524-1537.

Ma, Q., Kintner, C. and Anderson, D. J. (1996). Identification of neurogenin, a vertebrate neuronal determination gene. Cell 87, 43-52.

McCormick, M. B., Tamimi, R. M., Snider, L., Asakura, A., Bergstrom, D. and Tapscott, S. J. (1996). NeuroD2 and neuroD3: distinct expression patterns and transcriptional activation potentials within the neuroD gene family. Mol. Cell Biol. 16, 5792-5800.

Molkentin, J. D. and Olson, E. N. (1996). Combinatorial control of muscle development by basic helix-loop-helix and MADS-box transcription factors. Proc. Natl. Acad. Sci. USA 93, 9366-9373.

Naya, F. J., Huang, H. P., Qiu, Y., Mutoh, H., DeMayo, F. J., Leiter, A. B. and Tsai, M. J. (1997). Diabetes, defective pancreatic morphogenesis, and abnormal enteroendocrine differentiation in BETA2/neuroD-deficient mice. Genes Dev. 11, 2323-2334.

Naya, F. J., Stellrecht, C. M. and Tsai, M. J. (1995). Tissue-specific regulation of the insulin gene by a novel basic helix-loop-helix transcription factor. Genes Dev. 9, 1009-1019.

Neubuser, A., Koseki, H. and Balling, R. (1995). Characterization and developmental expression of Pax9, a paired-box-containing gene related to Pax1. Dev. Biol. 170, 701-716.

Offield, M. F., Jetton, T. L., Labosky, P. A., Ray, M., Stein, R. W., Magnuson, M. A., Hogan, B. L. and Wright, C. V. (1996). PDX-1 is required for pancreatic outgrowth and differentiation of the rostral duodenum. Development 122, 983-995.

Ohlsson, H., Karlsson, K. and Edlund, T. (1993). IPF1, a homeodomaincontaining transactivator of the insulin gene. EMBO J. 12, 4251-4259.

Ornitz, D. M., Palmiter, R. D., Messing, A., Hammer, R. E., Pinkert, C. A. and Brinster, R. L. (1985). Elastase I promoter directs expression of human growth hormone and SV40 T antigen genes to pancreatic acinar cells in transgenic mice. Cold Spring Harbor Symp. Quant. Biol. 50, 399-409.

Oster, A., Jensen, J., Serup, P., Galante, P., Madsen, O. D. and Larsson, L. I. (1998). Rat endocrine pancreatic development in relation to two homeobox gene products (Pdx-1 and Nkx 6.1). J. Histochem. Cytochem. 46, 707-715.

Pictet, R. L., Clark, W. R., Williams, R. H. and Rutter, W. J. (1972). An ultrastructural analysis of the developing embryonic pancreas. Dev. Biol. 29. 436-467.

Rall, L. B., Pictet, R. L., Williams, R. H. and Rutter, W. J. (1973). Early differentiation of glucagon-producing cells in embryonic pancreas: a possible developmental role for glucagon. Proc. Natl. Acad. Sci. USA 70, 3478-3482.

Rudnick, A., Ling, T. Y., Odagiri, H., Rutter, W. J. and German, M. S.
(1994). Pancreatic beta cells express a diverse set of homeobox genes. Proc. Natl. Acad. Sci. USA 91, 12203-12207.

Sander, M., Neubuser, A., Kalamaras, J., Ee, H. C., Martin, G. R. and German, M. S. (1997). Genetic analysis reveals that PAX6 is required for normal transcription of pancreatic hormone genes and islet development. Genes Dev. 11, 1662-1673.

Sassoon, D., Lyons, G., Wright, W. E., Lin, V., Lassar, A., Weintraub, H. and Buckingham, M. (1989). Expression of two myogenic regulatory factors myogenin and MyoD1 during mouse embryogenesis. Nature 341, 303-307.

Schonemann, M. D., Ryan, A. K., McEvilly, R. J., O'Connell, S. M., Arias, C. A., Kalla, K. A., Li, P., Sawchenko, P. E. and Rosenfeld, M. G. (1995) Development and survival of the endocrine hypothalamus and posterior pituitary gland requires the neuronal POU domain factor Brn-2. Genes Dev 9, 3122-3135.

Slack, J. M. (1995). Developmental biology of the pancreas. Development 121, $1569-1580$.

Smith, S., Ee, H., Conners, C. and German, M. (1999). Pairedhomeodomain transcription factor PAX4 acts as a transcriptional repressor in early pancreatic development. Mol. Cell. Biol. 19, 8272-8280.

Sommer, L., Ma, Q. and Anderson, D. J. (1996a). neurogenins, a novel family of atonal-related bHLH transcription factors, are putative mammalian neuronal determination genes that reveal progenitor cell heterogeneity in the developing CNS and PNS. Mol. Cell Neurosci. 8, 221-241.

Sommer, L., Ma, Q. and Anderson, D. J. (1996b). Neurogenins, a novel family of atonal-related bHLH transcription factors, are putative mammalian neuronal determination genes that reveal progenitor cell heterogeneity in the developing CNS and PNS. Mol. Cell Neurosci. 8, 221-241.

Sosa-Pineda, B., Chowdhury, K., Torres, M., Oliver, G. and Gruss, P. (1997). The Pax4 gene is essential for differentiation of insulin-producing beta cells in the mammalian pancreas. Nature 386, 399-402.

St-Onge, L., Sosa-Pineda, B., Chowdhury, K., Mansouri, A. and Gruss, P. (1997). Pax6 is required for differentiation of glucagon-producing alpha cells in mouse pancreas. Nature 387, 406-409.

St-Onge, L., Wehr, R. and Gruss, P. (1999). Pancreas development and diabetes. Curr. Opin. Genet. Dev. 9, 295-300.

Sussel, L., Kalamaras, J., Hartigan-O'Connor, D. J., Meneses, J. J., Pedersen, R. A., Rubenstein, J. L. and German, M. S. (1998). Mice lacking the homeodomain transcription factor Nkx2.2 have diabetes due to arrested differentiation of pancreatic beta cells. Development 125, 22132221.

Takebayashi, K., Takahashi, S., Yokota, C., Tsuda, H., Nakanishi, S., Asashima, M. and Kageyama, R. (1997). Conversion of ectoderm into a neural fate by ATH-3, a vertebrate basic helix-loop-helix gene homologous to Drosophila proneural gene atonal. EMBO J. 16, 384-395

Teitelman, G., Alpert, S., Polak, J. M., Martinez, A. and Hanahan, D. (1993). Precursor cells of mouse endocrine pancreas coexpress insulin, glucagon and the neuronal proteins tyrosine hydroxylase and neuropeptide Y, but not pancreatic polypeptide. Development 118, 1031-1039.

Teitelman, G. and Lee, J. K. (1987). Cell lineage analysis of pancreatic islet development: glucagon and insulin cells arise from catecholaminergic precursors present in the pancreatic duct. Dev. Biol. 121, 454-466.

Turque, N., Plaza, S., Radvanyi, F., Carriere, C. and Saule, S. (1994). PaxQNR/Pax-6, a paired box- and homeobox-containing gene expressed in neurons, is also expressed in pancreatic endocrine cells. Mol. Endocrinol. 8, 929-938.

Upchurch, B. H., Aponte, G. W. and Leiter, A. B. (1994). Expression of peptide YY in all four islet cell types in the developing mouse pancreas suggests a common peptide YY-producing progenitor. Development 120 245-252.

Woodcock-Mitchell, J., Mitchell, J. J., Low, R. B., Kieny, M., Sengel, P., Rubbia, L., Skalli, O., Jackson, B. and Gabbiani, G. (1988). Alphasmooth muscle actin is transiently expressed in embryonic rat cardiac and skeletal muscles. Differentiation 39, 161-166.

Wu, K. L., Gannon, M., Peshavaria, M., Offield, M. F., Henderson, E., Ray, M., Marks, A., Gamer, L. W., Wright, C. V. and Stein, R. (1997). Hepatocyte nuclear factor 3 beta is involved in pancreatic beta-cell-specific transcription of the pdx-1 gene. Mol. Cell Biol. 17, 6002-6013.

Yoshida, T. and Hanahan, D. (1994). Murine pancreatic ductal adenocarcinoma produced by in vitro transduction of polyoma middle $\mathrm{T}$ oncogene into the islets of Langerhans. Am. J. Pathol. 145, 671-684. 